\section{Barisan}

Mahasiswa IImu Pemerintahan Univer-

sitas Muhammadiyah Yogyakarta

Email: uchenklppmstisip@yahoo.co.id

\section{Zuly Qodir}

Dosen IImu Pemerintahan Universitas Muhammadiyah Yogyakarta

Email: zuly_qodir@yahoo.com

http://dx.doi.org/10.18196/

igpp.2016.0049

\title{
Analisis Kepemimpinan Pemerintah Kabupaten Sidenreng Rappang Dari Aspek Ekonomi, Sosial dan Politik
}

\begin{abstract}
This research to intend for the describe and analyze about the political participation a minority communities by taking the case on Towani Tolotang in Sidenreng Rappang. The method used in this research is descriptive qualitative and analysis is done through collection, reduction, and categorizing. The result showed that political participation Towani Tolotang high at $64.3 \%$ Towani Tolotang high political participation can not be separated from the strong relationship that woke persuasive in the group through activities Tudang Sipulung (seated together). The participation aims to build a network/political connection to the government in order to maintain its existence. Tolotang Towani behavior in choosing a traditional-critical. Traditional form that they always choose the candidate who comes from the group, while the critical Hape that they see the private candidates before settling on the choice. The factors that influences the high participation that is the compromise between Towani Tolotang with the government. The form of compromise that is all the government did not prohibit their customary activities and the government also does not deviate from the NKRI then along the Towani Tolotang always believe and support the government.

Keywords: Political Participation, Towani Tolotang
\end{abstract}

\begin{abstract}
ABSTRAK
Penelitian ini bertujuan untuk menjelaskan dan menganalisis partisipasi politik kelompok minoritas dalam pemilihan umum legislatif 2014 dengan mengambil kasus pada Towani Tolotang di Kabupaten Sidenreng Rappang. Metode yang digunakan dalam penelitian ini adalah deskriptif kualitatif dan analisis data dilakukan melalui pengumpulan data, mereduksi data, dan mengkategorikan data. Hasil penelitian ini menunjukkan bahwa partisipasi politik Towani Tolotang Tinggi yaitu 64,37 \%. Tingginya partisipasi politik Towani Tolotang tidak terlepas dari kuatnya hubungan persuasif yang terbangun di dalam kelompok tersebut melalui kegiatan Tudang Sipulung (duduk bersama). Partisipasi tersebut ber tujuan untuk membangun jaringan/koneksi politik kepada pemerintah demi mempertahankan eksistensinya. Perilaku Towani Tolotang dalam memilih yaitu tradisional-kritis. Bentuk tradisionalnya yaitu mereka senantiasa memilih calon yang berasal dari kelompoknya, sedangkan bentuk kritisnya yaitu mereka melihat pribadi calon tersebut sebelum menetapkan pilihan. Adapun faktor-faktor yang mempengaruhi tingginya partisipasi tersebut yaitu dengan kompromi antara Towani Tolotang dengan pemerintah. Adapun bentuk komprominya yaitu sepanjang pemerintah tidak melarang kegiatan adatnya dan pemerintah juga tidak melenceng dari NKRI maka sepanjang itu pula Towani Tolotang senantiasa percaya dan mendukung pemerintah.

Kata Kunci: Partisipasi politik, Towani Tolotang.
\end{abstract}




\section{PENDAHULUAN}

Partisipasi merupakan salah satu aspek penting demokrasi. Asumsi yang mendasari demokrasi (dan partisipasi) adalah orang yang paling tahu tentang apa yang paling baik bagi dirinya adalah orang itu sendiri (Surbakti, 2013:179). Partisipasi politik meliputi tanggapan internal seperti persepsi, sikap, orientasi dan keyakinan serta tindakan-tindakan nyata seperti pemberian suara, protes, lobi dan sebagainya.

Partisipasi politik Towani Tolotang yang erat kaitannya dengan partai Golkar merupakan salah satu bukti nyata dari penjelasan diatas. Warga Towani Tolotang di Kabupaten Sidenreng yang berjumlah 24482 jiwa dengan jumlah wajib pilih 16752 jiwa hampir dapat dipastikan bahwa 90\% akan menjatuhkan pilihannya kepada partai berlambang pohon beringin tersebut. Hal ini sejalan dengan pengakuan Mattau Kulattang pada saat pemilukada Sidenreng Rappang tahun 2013 yang lalu, bahwa ; "Siapapun yang diusung Partai Golkar, di Pilbup mendatang, maka kita pastikan akan memberikan dukungan maksimal”.

Dengan fakta diatas, menunjukkan bahwa Towani Tolotang merupakan suatu kekuatan politik ditingkat lokal khususnya di Sidenreng Rappang. Keberhasilan Towani Tolotang untuk mendudukan wakilnya di DPRD sidrap menjadi salah satu bukti adanya persatuan kuat yang mereka bangun. Akan tetapi keberhasilan tersebut juga merupakan suatu hal yang kontradiksi dengan apa yang telah menjadi pengakuan dari tokoh Towani Tolotang sebelumnya yang mengatakan, bahwa kelompok mereka akan senantiasa mendukung partai Golkar dalam even politik apapun, karena partai Golkar merupakan bagian dari mereka.

Pemilu merupakan cara yang terkuat bagi rakyat untuk berpartisipasi di dalam sistem demokrasi perwakilan modern. Sebuah instrument yang diperlukan bagi partisipasi ialah sistem pemilu. Jika sistem ini tidak memperbolehkan warga Negara untuk 
menyatakan pilihan-pilihan dan preferensi politik mereka, maka pemilu bisa menjadi kegiatan yang hampir tidak bermakna. Sigit Pamungkas mendefinisikan sistem pemilu sebagai seperangkat metode atau aturan untuk mentransfer suara pemilih kedalam suatu lembaga perwakilan (Efriza, 2012:356). Lebih lanjut sigit menjelaskan "sistem pemilu adalah metode yang di dalamnya suara-suara yang diperoleh dalam pemilihan diterjemahkan dalam parlemen oleh partai-partai dan para kandidat".

Partisipasi politik Towani Tolotang menjadi menarik untuk diteliti karena mereka dikenal sebagai kelompok yang minoritas dan sekaligus masyarakat pendatang berdasarkan sejarah. Tetapi dalam perhelatan kontestasi politik pada pemilihan legislatif 2014, mereka dapat membuktikan bahwa mereka adalah kelompok yang solid. Meski demikian partisipasi politik Towani Tolotang kemudian menjadi satu tanda tanya karena mereka juga dikenal sebagai kelompok masyarakat yang taat terhadap pemimpinnya atau dengan kata lain apapun yang menjadi perintah/kehendak dari uwa' atau uwa'ta maka itulah yang mereka lakukan.

Berdasarkan dari penjelasan diatas maka penulis berkesimpulan untuk melakukan penelitian dengan judul PARTISIPASI POLITIK KELOMPOK MINORITAS (Studi tentang Towani Tolotang di kabupaten Sidenreng Rappang).

\section{KERANGKA TEORI}

\section{PARTISIPASI POLITIK}

Partisipasi adalah keterlibatan individu dalam suatu interaksi sosial dalam suatu kegiatan di masyarakat yang tumbuh dari kesadaran diri sendiri tanpa adanya tekanan atau paksaan serta penuh dengan rasa tanggung jawab. Sedangkan politik menurut Elly M. Setiadi dan Usman Kolip (2013:4) politik dapat dipahami sebagai proses pembentukan dan pembagian kekuasaan dalam masyarakat antara lain berwujud proses pembuatan keputusan, 
khususnya dalam negara. Dapat juga dipahami sebagai proses interaksi antara pihak penguasa dan pihak yang dikuasai.

Menurut Hardwick dalam Budiyanto (2007:20) partisipasi politik memberi perhatian pada cara-cara warga negara berinteraksi dengan pemerintah, warganegara berupaya menyampaikan kepentingankepentingan mereka terhadap pejabat-pejabat publik agar mampu mewujudkan kepentingan-kepentingan tersebut.

Partisipasi politik dapat terwujud dari pelbagai (berbagai) bentuk. Studi-studi tentang partisipasi dapat menggunakan skema-skema klasifikasi yang agak berbeda-beda, namun kebanyakan riset belakangan menggunakan jenis perilaku sebagai berikut (Huntington, 1995:16):

\section{A. KEGIATAN PEMILIHAN}

Kegiatan pemilihan merupakan serangkaian kegiatan yang dilaksanakan dalam pemilihan umum. Kegiatan ini tidak hanya mencakup penggunaan hak suara tetapi juga meliputih proses persiapan dari pelaksana dan juga kegiatan kampanye untuk mencari dukungan guna mempengaruhi hasil pemilihan. Hal ini sejalan dengan pendapat Goel dalam Gatara (2009:316), bahwa:

“........ Party and campaign workers: bekerja untuk partai politik atau kandidat, meyakinkan orang lain tentang bagaimana memilih, menghadiri pertemuan-pertemuan, menyumbangkan uang kepada partai politik atau kandidat, bergabung dan mendukung partai politik, dipilih menjadi kandidat partai politik...."

\section{B. LOBBYING}

Lobi merupakan suatu bentuk partisipasi politik yang dilaksanakan dengan cara membangun komunikasi politik terhadap induvidu atau kelompok dengan maksud untuk mencari dukungan dari para pemimpin-pemimpin atau tokoh yang dianggap memiliki pengaruh di tengah masyarakat. Kegiatan ini dilaksanakan untuk 
membangun suatu kekuatan, sehingga dapat memberi kemudahan untuk meloloskan kepentingan politik atau pencalonannya dalam pemilihan umum.

Pengertian lobi menurut AB Susanto dalam Panuju (2018:18) adalah "Melobi pada dasarnya merupakan usaha yang dilaksanakan untuk mempengaruhi pihak-pihak yang menjadi sasaran agar terbentuk sudut padang positif terhadap topik pelobi, dengan demikian diharapkan memberikan dampak positif bagi pencapaian tujuan".

\section{KEGIATAN ORGANISASI}

Kegiatan organisasi adalah usaha atau pekerjaan yang dilakukan secara berkelompok demi mencapai suatu tujuan yang sama.Kegiatan organasi dalam kaitannya dengan partisipasi politik adalah bentuk kegiatan yang dilaksanakan secara berkelompok dengan tujuan untuk mempengaruhi keputusan politik. menurut P. Huntington (1995:17) kegiatan organisasi merupakan partisipasi sebagai anggota atau pejabat dalam suatu organisasi yang tujuannya yang utama dan eksplisit adalah mempengaruhi keputusan pemerintah.

Kegiatan organisasi dalam pemilihan umum yang merupakan bagian dari partisipasi politik dan merupakan hal yang sering dijumpai ditengah-tengah masyarakat. Salah satu bentuk kegiatan yang dilaksanakannya yaitu dengan melaksanakan suatu perayaan atau event tertentu dengan maksud untuk mendekatkan figur atau calonnya kepada masyarakat sebagai calon pemilih.

\section{MENCARI KONEKSI (CONTACTING)}

Menurut P. Huntington (1995:17) mencari koneksi (contacting) merupakan tindakan perorangan yang ditujukan terhadap pejabatpejabat pemerintah dan biasanya dengan maksud memperoleh manfaat bagi hanya satu orang atau segelintir orang. Dari definisi tersebut dapat dipahami bahwa bentuk kegiatan tersebut 
26 dilaksanakan dalam pemilihan umum dengan maksud untuk membagun adanya koneksi kepada pemerintah.

Dengan memiliki koneksi di dalam jaringan pejabat pemerintah, biasanya urusan-urusan menjadi lebih mudah dan kepentingankepentingan yang bersifat pribadi dapat diperoleh (Sastroatmodjo, 1995:80). Pembangunan koneksi merupakan suatu hal tidak terpisahkan dari pelaksanaan pemilihan umum karena hal ini dianggap sebagai suatu cara untuk membangun koneksi/jaringan yang efektif.

\section{E. TINDAK KEKERASAN (VIOLENCE)}

Bentuk partisipasi politik dalam wujud tindak kekerasan (violence) merupakan tindakan yang dituangkan berdasarkan tinggi rendahnya pengetahuan politik dan tingkat kepercayaan seseorang terhadap pemerintah. Menurut Surbakti (2013:185) partisipasi politik militan radikal, yakni apabila kesadaran politik tinggi tetapi kepercayaan terhadap pemerintah sangat rendah. Selanjutnya, apabila kesadaran politik sangat rendah tetapi tingkat kepercayaan terhadap pemerintah sangat tinggi.

Bentuk partisipasi ini, dilakukan dalam pemilihan umum melalui dukungan atau penolakan individu/kelompok terhadap partai atau kandidat pemerintah. Nazaruddin dkk dalam Efriza (2010:177) mengatakan bahwa bentuk yang lebih jelas lagi daripada dukungan yang diberikan kepada pemerintah adalah adanya kesediaan atau kemauan dari anggota-anggota masyarakat memilih partai pemerintah di dalam pemilu.

\section{KONSEPSI PEMILIHAN UMUM}

Pemilihan Umum adalah memilih seorang penguasa, pejabat atau lainnya dengan jalan menuliskan nama yang dipilih dalam secarik kertas atau dengan memberikan suaranya dalam pemilihan (Al-Iman, 2004:29). Sedangkan, menurut Undang-undang Nomor 8 Tahun 
2012 tentang Pemilihan Umum Anggota Dewan Perwakilan Rakyat, Dewan Perwakilan Daerah, dan Dewan Perwakilan Rakyat Daerah Pemilihan Umum adalah sarana pelaksanaan kedaulatan rakyat yang dilaksanakan secara langsung, umum, bebas, rahasia, jujur dan adil dalam Negara Kesatuan Republik Indonesia berdasarkan Pancasila dan Undang-undang Dasar Negara Republik Indonesia tahun 1945.

Salah satu wujud demokrasi dalam pengertian "prosedur untuk membentuk pemerintahan secara luas", ialah pemilihan umum (pemilu). Dalam kata lain, pemilu adalah pengejewantahan penting dari "demokrasi prosedural". Berkaitan dengan ini Samuel P. Huntington dalam Gatara (2008:207), menyebutkan bahwa prosedur utama demokrasi adalah pemilihan para pemimpin secara kompetitif oleh rakyat yang mereka (bakal) pimpin. Selain itu, pemilu sangat sejalan dengan semangat demokrasi secara subtansi atau "demokrasi subtansial”, yakni demokrasi dalam pengertian pemerintahan yang diselenggarakan dari rakyat, oleh rakyat, dan untuk rakyat. Artinya, rakyatlah yang memegang kekuasaan tertinggi (kedaulatan).

\section{METODE PENELITIAN}

Penelitian ini menggunakan metode studi kasus (case studies) yaitu penelitian yang dilakukan secara intensif, terinci, dan mendalam terhadap suatu organisasi, lembaga, atau gejala tertentu (Arikunto, 2013:185). Kasus dalam penelitian ini adalah partisipasi politik Towani Tolotang dalam pemilihan legislatif 2014 di Kabupaten Sidenreng Rappang. Oleh karena itu, peneliti berusaha mengembangkan konsep dan menghimpun data yang terjadi dilapangan, mempelajari secara intensif kasus yang telah terjadi dan menggali sebanyak-banyaknya pendapat dari pihak yang dianggap berkompeten dengan masalah yang diteliti.

Pedekatan yang dilakukan melalui metode kualitatif. Metode penelitian ini bertujuan untuk mendeskripsikan, mancatat, menganalisa, dan menginterpretasikan kondisi-kondisi yang terjadi 
dilapangan. Dengan metode ini diharapkan peneliti mampu mengetahui secara mendalam, untuk mengungkapkan permasalahan tersebut dengan mendeskripsikan secara jelas dan faktual sesuai dengan data-data yang diperoleh dilapangan, sehingga peneliti dapat mengetahui periloku politik dan faktor-faktor yang mempengaruhin partisipasi politik Towani Tolotang dalam pemilihan legislatif 2014 di Sidenreng Rappang.

\section{PEMBAHASAN}

\section{PARTISIPASI POLITIK TOWANI TOLOTANG DALAM PEMILIHAN LEGISLATIF 2014 KEGIATAN PEMILIHAN}

Kegiatan pemilihan yang dilakukan oleh Towani Tolotang berjalan secara normal dan tidak ditemukan adanya kegiatankegiatan yang menyimpang dari apa yang seharusnya. Kampanye dalam kelompok ini tidak memiliki batasan tertentu, karena para calon atau kelompok pendukung dari kandidat yang lain juga melaksanakan kampanye atau sosialisasi politiknya dalam kelompok ini.

Menurut uwa' Eja (B. Edi Slamet), bahwa:

"kampanye yang dilakukan sekarang tidak lagi sesuai dengan yang dulu pernah ada. Karena kampanye sekarang dalam hal ini mobilisasi massa, saat ini orang tua tidak lagi mengikat para warga untuk menetapkan pilihannya" (wawancara, kamis 5 maret 2015, pukul 11:20).

Orang tua yang dimaksud beliau dalam pernyataan tersebut adalah pemimpin dari kelompok warga ini yaitu; Uwa' dan Uwa'ta. Nilai-nilai demokrasi pada dasarnya ditanamkan secara mendalam oleh Towani Tolotang, sebagaimana yang diutarakan oleh Wa' Eja tersebut bahwa sesungguhnya tidak ada lagi ikatan-ikatan yang diberikan oleh orang tua terkait penetapan pilihan politik warganya. Menurut Farmalinda (2012) bahwa, Agama atau kepercayaan Towani 
Tolotang meyakini bahwa kekuasaan tertinggi adalah Dewa SeuwaE (Tuhan Yang Maha Esa), mengenai kekuatan Dewata SeuwaE yang berkuasa dalam segala hal menurunkan pemimpin ke dunia yang dipercaya sebagai titisan Dewa yang mengatur tata tertib manusia dan agar mereka taat kepada pemilik kekuasaan yang terbatas tersebut.

Tudang sipulung dilakukan oleh warga Towani Tolotang secara berkesinambungan meskipun tanpa adanya kontestasi politik. Seringnya kegiatan tersebut mereka lakukan membuat kelompok mereka memiliki hubungan yang semakin kuat, maka dengan demikian kekuatan politik yang mereka miliki menyatu. Menurut Uwa' Eja (B. Edi Slamet) bahwa:

"dalam kelompok kami, selalu diadakan kegiatan tudang sipulung setiap seminggu sekali, bahkan terkadang dua kali dalam seminggu" (wawancara dengan Uwa' Eja, kamis 5 maret 2015, 12:41).

\section{LOBBYING}

Lobby politik merupakan sesuatu yang sudah pasti ada dalam proses Pemilu. Pelaksanaannya pun bermacam-macam, yaitu mulai dari pengumpulan/mobilisasi massa sampai pada kegiatan mempengaruhi individu. Tidak dapat disangka lagi bahwa kejadian serupa juga terdapat di dalam kelompok Tolotang, seperti yang diakui oleh Uwa' Lasse' bahwa:

“mega mato tau pole marellau lao okko idi', tapi makkotomitu assele'na nasaba purani laikadoe idimaneng tette'ki' massidi'. Artinya "banyak juga orang yang datang meminta kekita, tapi hasilnya tetap begitu karena sudah menjadi kesepakatan kita untuk tetap bersatu" (wawancara dengan Uwa' Lasse', Senin 9 maret 2015 pukul 19.37).

Komitmen untuk tetap bersatu diantara mereka menjadikan kelompok ini sebagai kelompok yang menjadi basis kekuatan politik, maka dengan demikian setiap Caleg yang memiliki kedekatan dengan mereka tentunya sudah dapat memperhitungkan kekuatan 
yang dia miliki.

Terkait dengan urusan Lobby dalam kelompok ini ditarik kesimpulan bahwa yang mereka lakukan adalah mempertahan budaya Tudang Sipulung (duduk bersama). Lewat dari kegiatan tersebut mereka menyampaikan nilai-nilai kepada setiap warganya.

Kegiatan organisasi

Kegiatan organisasi dalam partisipasi politik merupakan kegiatan berkelompok yang dilakukan dengan tujuan untuk mempengaruhi keputusan politik. Dengan melihat jumlah penduduk Towani Tolotang yang ada di Kabupaten Sidenreng Rappang memungkinkan kita memandangnya sebagai kelompok yang dapat mempengaruhi keputusan politik baik keputusan pilitik individu maupun pemerintahan. Pada Pemilu 2014 terdapat 16752 jiwa penduduk Towani Tolotang yang memiliki hak suara.

Pada pelaksanaan pemilihan umum legislatif, peluang terjadinya Golput atau ketidak ikutsertaan masyarakat berpartisipasi merupakan suatu hal yang umum terjadi. Hal tersebut terjadi pada pemilihan umum legislatif 2014 di Kabupaten Sidenreng Rappang. Pada Pemilu tersebut, tingkat partisipasi masyarakat dalam pemilihan umum yaitu 74,78\%. Adapun partisipasi pemilu dari kelompok Towani Tolotang dalam memilih calon yang bersal dari kelompoknya sendiri yaitu $64,37 \%$. Dari asumsi tersebut maka secara matematis memungkinkan kelompok Towani Tolotang meraih 3 kursi di parlemen apabila mereka tetap solid dalam kelompoknya. Untuk mengetahui secara lebih rinci tentang Pemilu legislatif 2014 di Kabupaten Sidenreng Rappang dapat kita lihat pada tabel 1.

Pada tebel tersebut diatas terlihat dengan jelas bahwa tingkat partisipasi masyarakat dalam pemilihan umum legislatif 2014 berbeda-beda di setiap daerah pemilihan. Begitupun juga dengan partisipasi Towani Tolotang untuk memilih calon yang berasal dari kelompoknya. Partisipasi Towani Tolotang yang terbesar terdapat di daerah pemilihan Sidrap 2 dan 3. Yang pada daerah pemilihan 2 
tingkat partisipasinya 99,39\% dengan 3640 total suara dari 5628 wajib pilih. Towani Tolotang di daerah pemilihan Sidrap 2 berhasil meraih kursi di parlemen yaitu LannaE dari partai Golkar.

\section{TABEL. 1 DESKRIPSI PEMILU LEGISLATIF KABUPATEN SIDENRENG RAPPANG} TAHUN 2014

\begin{tabular}{llllll}
\hline Keterangan & Sidrap & Sidrap 1 & Sidrap 2 & Sidrap 3 & Sidrap 4 \\
\hline $\begin{array}{l}\text { Pemilih kabupaten } \\
\text { Sidenreng Rappang }\end{array}$ & 224.909 & 52.526 & 60.488 & 55.926 & 55.969 \\
pemilih tolotang & 16752 & 3222 & 5628 & 9675 & 193 \\
$\begin{array}{l}\text { tingkat partisipasi politik } \\
\text { Towani Tolotang memilih }\end{array}$ & & $39,60 \%$ & $99,39 \%$ & $60,65 \%$ & $0 \%$ \\
$\begin{array}{l}\text { calon dari kelompoknya } \\
\begin{array}{l}\text { Tingkat partisipasi } \\
\text { masyarakat sidrap }\end{array}\end{array}$ & $74,78 \%$ & $74,58 \%$ & $75,12 \%$ & $77,71 \%$ & $71,68 \%$ \\
$\begin{array}{l}\text { pembagian kursi } \\
\text { konstituen yang diwakili }\end{array}$ & 35 & 8 & 9 & 9 & 9 \\
\hline
\end{tabular}

Sumber: Olah Data Penelitian 2015

Dari pernyatan serta penjelasan diatas dapat ditarik kesimpulan bahwa kegiatan organisasi Towani Tolotang khususnya kegiatan politiknya sangat sarat dengan salah satu partai politik yaitu partai Golkar. Meskipun pada kenyataannya terdapat salah seorang wakil rakyat dari kelompok mereka yang tidak berasal partai tersebut. Hal ini terjadi karena partai tersebut, juga merupakan salah satu partai pendukung pemerintah sebagaimana diakui oleh Azis Laise, bahwa:

"sebagaimana kita ketahui bersama partai Gerindra juga adalah partainya pemerintah, kita tahu bahwa siapa bupati sekarang dan siapa ketua Gerindra Kabupaten Sidrap, mereka itukan dua orang yang bersaudara" (wawancara Jum'at 6 maret 2015 pukul 10:00).

Pada pemilihan umum legislatif tahun 2014 calon legislatif dari Towani Tolotang mendapatkan suara sekitar 10784 atau 64,37\% dari total jumlah pemilik suara tolotang yang terdapat dalam beberapa partai politik. Dari hasil perolehan suara tersebut mereka mendapatkan kursi 3 (tiga) di parlemen. Ketiga orang yang terpilih 
tersebut masing-masing dicalonkan oleh partai Gerindra dan partai Golkar.

\section{MENCARI KONEKSI (CONTACTING)}

Salah satu bentuk kegiatan yang dilakukan oleh kelompok Tolotang adalah dengan memperkuat persatuan yang ada diantara mereka, maka dengan demikian setiap warga yang memiliki peranan baik dalam pemerintahan maupun dalam organisasi kemasyarakatan serta lembaga-lembaga yang lainnya, akan memberi koneksi ke dalam kelompok mereka. Adanya jaringan tersebut membuat mereka untuk lebih mudah menyelesaikan segala macam bentuk urusannya. Hal ini sejalan dengan pendapat Hasse J (2010) bahwa, meskipun Tolotang Towani yang terus-menerus mengalami pertumbuhan dalam jumlah banyak, tetapi tetap dibawah ancaman yang harus dihadapi. Dengan demikian, keberadaan tolotang towani tidak pernah lepas dari berbagai bentuk diskriminasi.

Mengingat besarnya tantangan yang dihadapi oleh Tolotang Towani tersebut, maka salah satu langkah yang ditempu untuk mempertahankan kelompoknya yaitu dengan mencari koneksi (contacting) yang kuat secara vertikal dan horisontal. Koneksi secara vertikal yaitu koneksi mereka kepada pemerintahan, sedangkan koneksi secara horisontal yaitu koneksi antar sesama warga tolotang dan masyarakat secara umum.

Pertama, koneksi vertikal dibangun dengan cara menjalin hubungan yang baik dengan pemerintah. Hubungan ini diaplikasikan dengan cara mereka yang akan senantiasa menjadi pendukung pemerintah dan partai politik pendukung pemerintah khususnya partai Golkar.

Kedua, koneksi horisontal yaitu hubungan yang ada antara sesama warga Towani Tolotang dan kepada masyarakat umum. Hubungan antara sesama warga Towani Tolotang dibentuk melalui kegiatan yang rutin mereka laksanakan yaitu Tudang Sipulung (duduk 
bersama), sedangkan hubungan kepada masyarakat secara umum mereka laksanakan melalui keaktifan mereka dalam kegiatankegiatan gotong-royong ditengah-tengah masyarakat.

\section{TINDAK KEKERASAN (VIOLENCE)}

Keberhasilan yang dicapai oleh kelompok Tolotang dalam Pemilu Legislatif 2014 yaitu dengan duduknya 3 (tiga) orang Anggota Dewan Perwakilan Rakyat Daerah (DPRD) dari komunitas ini, yang mana para wakil rakyat tersebut berasal dari 2 partai politik, yaitu Partai Golkar dan Partai Gerindra. Keberhasilan ini tidak terlepas dari upaya yang dilakukan oleh kelompok ini dalam mempertahankan komitmen yang sudah mereka bangun sejak dini. Hal sejalan dengan pengakuan Uwa' Eja (B. Edi Slamet), bahwa:

"tidak ada upaya untuk memberikan tekanan karena memang kedekatan kita sudah tertanam sejak dini" (wawancara kamis 5 maret 2015 pukul 13:50).

Pemberian tindakan kekerasan atau tekanan kepada terkait penetapan pilihan politik dalam kelompok Tolotang tidak ada. Tindakan ini merupakan langkah yang tidak penting sebab mereka sudah memiliki hubungan yang dekat dan tertanam sejak dini.

\section{KESIMPULAN}

\section{PARTISIPASI POLITIK}

Dari pemaparan dan analisis pada pada bab-bab sebelumnya, maka peneliti berkesimpulan bahwa partisipasi politik kelompok minoritas yaitu Towani Tolotang di Kabupaten Sidenreng Rappang pada Pemilu Legislatif 2014 sangat tinggi yaitu 64,37\%. Tingginya partisipasi tersebut dapat dilihat sebagai berikut:

a. Kegiatan pemilihan

Kegiatan pemilihan yang dilakukan oleh masyarakat Towani Tolotang yaitu membangun kekuatan politik sejak dini yang mengakibatkan mereka sangat sulit menerima pengaruh dari luar 
kelompoknya. Kelompok Towani Tolotang sulit bahkan tidak mungkin memilih calon legislatif yang selain dari kelompoknya, begitupun dengan sebaliknya calon Towani Tolotang tidak mungkin mendapatkan dukungan dari masyarakat di luar tolotang.

b. Lobbying

Bentuk lobi yang dilakukan oleh kelompok masyarakat Towani Tolotang yaitu membangun komitmen antar sesamanya serta membangun kompromi dengan pemerintah. Bentuk kompromi yang dihasilkannya adalah mereka akan selalu mendukung pemerintahan Kabupaten Sidenreng Rappang sepanjang kegiatan adat mereka tidak dihalangi.

c. Kegiatan Organisasi

Kegiatan organisasi kelompok masyarakat Towani Tolotang adalah mempertahankan tradisi bugis yaitu tudang sipulung (duduk bersama) serta jiwa gotong royong yang kuat. Secara politik kegiatan organisasi mereka yaitu tidak lagi bertahan pada satu partai politik saja melainkan terbagi ke dalam beberapa partai politik.

d. Mencari koneksi (contacting)

Koneksi yang dibangun oleh kelompok masyarakat Towani Tolotang yaitu koneksi secara vertikal dan horisontal. Koneksi vertikal adalah hubungan antara kelompok Towani Tolotang dengan pemerintah Sidenreng Rappang, sedangkan koneksi horisontalnya adalah hubungan antara sesama warga tolotang dan juga kepada masyarakat secara umum.

e. Tindak kekerasan (violence)

Dalam kelompok Towani Tolotang tidak mengenal istilah tindak kekerasan terkait partisipasi politiknya. Hal ini dikarenakan tingginya kepercayaan mereka terhadap pemimpinnya yang dianggap sebagai titisan dewa dimuka bumi. 


\section{DAFTAR PUSTAKA}

\section{BUKU-BUKU}

Budiardjo, Miriam,2008. Dasar-Dasar Ilmu Politik. PT Gramedia Pustaka Utama. Jakarta

Budiyanto. 2007. Pendidikan Kewarganegaraan. Jakarta: Erlangga.

Bongdan Robert C and Sari Knopp Biklen, 1982. Qualitative Research for Education: an. Introduction to Theory and Methods. Boston: Alin and Bacon.

Darmawan, Ikhsan, 2013. Analisis Sistem Politik Indonesia. Alfabeta. Bandung

Efriza, 2012. Political Explore: Sebuah Kajian IImu Politik. Alfabeta. Bandung

Elly M. Setiadi dan Usman Kolip. 2013. Pengantar Sosiologi Poitik. Jakarta: Kencana Prenadamedia Grup

Gatara, Sahid, 2009. Ilmu Politik: Memahami dan Menerapkan. Pustaka Setia. Bandung

Huntington, P. Samuel, 1994. Partisipasi Politik di Negara Berkembang. Rineka Cipta. Jakarta. (Terjemahan)

Huntington, P. Samuel, 2004, Tertib Politik: pada masyarakat yang sedang berubah. Rajawali Press. Jakarta

Kusnaedi. (2009). Memenangkan Pemilu dengan Pemasaran Efektif. Bekasi: Duta Media Tama.

La Nora, Ghazali Ama, 2014. Ilmu Komunikasi Politik. Mercu Buana. Yogyakarta

Lincoln, Yvona S, dan Egon G., Guba, 1985. Naturalistic Inquiry. Baverly Hills: Sage Publication

Mochtar, Hilmy, 2011. Demokras dan Politik Lokal di Kota Santri. UB Press. Malang

Muhammad Al-Iman, Abu Nashr. Membongkar Dosa-dosa Pemilu. Prisma Media, Jakarta

Nursal, Adman. (2004). Political Marketing: Strategi Memenangkan Pemilihan umum. Jakarta: Gramedia Pustaka Utama.

Nimmo, Dan, 2010. Komunikasi Politik: Khalayak dan Efek. Rosdakarya. Bandung Panuji, Redi, 2010. Jago, Lobi dan Negosiasi. Interprebook. Jakarta

Sastroatmodjo, Sudijono, 1995. Partisipasi politik. Ikip Semarang press. Semarang Scott, John, 2012. Teori Sosial: Masalah-Masalah Pokok dalam Sosiologi. Pustaka Pelajar. Yogyakarta

Surbakti, Ramlan, 2013. Memahami Ilmu Politik. Edisi Revisi. Grasindo. Jakarta

\section{JURNAL}

Agustino, Leo dan Yussoff, Mohammad Agus, 2009. pemilihan Umum Dan Perilaku Pemilih: Analisis Pemilihan Presiden 2009 Di Indonesia. Jurnal Kajian Politik Dan Masalah Pembangunan.

Farmalinda, Erlina, 2012. Komunitas Towani Tolotang Di Amparita Kabupaten 
Sidenreng Rappang (Study Tentang Pola Pendidikan Beragama). Unhas Hasse J. Deeksistensi Agama Lokal Di Indonesia. Jurnal AL-FIKR, Volume 15 Nomor 3 Tahun 2011

Hasse J. Kebijakan Negara Terhadap Agama Lokal "Towani Tolotang" Di Kabupaten Sidrap, Sulawesi Selatan. Jurnal Studi Pemerintahan Volume 1 Nomor 1 Agustus 2010

Rusli, Muh. Kearifan Lokal Masyarakat Towani Tolotang Di Kabupaten Sidenren Rappang. Jurnal Al- Ulum Volume. 12, Nomor 2, Desember 2012 Nur Rochimah, Tri Hastuti. Pentingnya Memahami Partisipasi politik dalam Political Marketing. Jurnal Komunikatot, VOLUME 1 NO. 1 MEI 2009

\section{SUMBER LAIN}

Sk. Dirjen Bimas Beragama Hindu Bali/Budha No. 2/1966 tanggal 06 Oktober 1966 Undang-undang Nomor 8 Tahun 2012 tentang Pemilihan Umum Anggota Dewan Perwakilan Rakyat, Dewan Perwakilan Daerah, dan Dewan Perwakilan Rakyat Daerah

http://politik.kompasiana.com/2013/05/07/bantah-pecah-komunitas-tolotang-solidke-ridho-ii-553784.html. Diakses: 12:00 7/11/2014 http://brainly.co.id/tugas/263751 diakses: 12;24 9/11/2014 